\title{
EIJEST
}

\section{APPLICABILITY OF INDUSTRIAL ENGINEERING TECHNIQUES IN SMALL AND MEDIUM SIZE ENTERPRISES VIA A QUESTIONAIRE*}

\author{
Gamal M. Nawara, Mahasen M. H. Khater, and M. A Mostafa ${ }^{+}$ \\ Industrial Eng. Dept., Faculty of Engineering, Zagazig University, Zagazig, Egypt
}

\begin{abstract}
This paper intends to measure the extent to which Industrial Engineering techniques are applied in small and medium-size enterprises to manage productivity, diagnose reasons of low usability of IE techniques. It describes several definitions for SMEs and their great role in the Egyptian economy. So, a questionnaire was designed to establish a fact base about the use of IE techniques in regional SMEs in Egypt. The survey results were analyzed to diagnose the percent of applicability of these techniques and their relationship with the type of industry and the volume of the enterprise. The business mix was selected to embrace the manufacturing and trade sectors separately and to determine whether different business groups had different approaches to the use of best-practice IE techniques. The questionnaire had several sections with selected questions to examine the usability of IE techniques with each question having several choices to select from. Also, direct observation was made for about two days in each industrial enterprise and some hours for trade enterprises. An excel sheet was designed to analyze the collected data, getting the representative tables. Finally the results were analyzed to determine the main causes of difficulty of applying the IE techniques in SMEs.
\end{abstract}

KEY WORDS: IE techniques, small and medium enterprises, demand forecasting, facility planning, transportation, method study, work measurement, production planning and control, quality control, and maintenance.

\section{APPLICABILITE DES TECHNIQUES GÉNIE INDUSTRIEL DANS LES PETITES ET MOYENNES ENTREPRISES PAR UN QUESTIONNAIRE}

\section{RÉSUMÉ :}

Cette mesure du papier dans quelle mesure, le Génie Industriel (IE) des techniques, sont appliquées dans les petites et moyennes entreprises (PME) de gérer la productivité, de diagnostiquer les raisons de facilité d'utilisation de techniques à faible IE. Il décrit un grand nombre de définitions pour les PME et leur rôle important dans l'économie égyptienne. Ainsi, un questionnaire a été conçu pour établir la base factuelle sur l'utilisation de techniques d'IE dans les PME régionales en Egypte. Les résultats du sondage ont été analysés pour diagnostiquer le pour cent de l'applicabilité de ces techniques et leur relation avec le type d'industrie et le volume de l'entreprise. Le mix d'activités a été choisi pour embrasser les secteurs de la fabrication et le commerce séparément et pour déterminer si des groupes d'affaires différents ont des approches différentes pour l'utilisation des meilleures techniques IE pratique. Le questionnaire avait plusieurs sections avec des questions choisies afin d'examiner l'utilité des techniques d'IE que chaque question a plusieurs choix et le gestionnaire responsable peut choisir un de ces choix. Le questionnaire n'a pas été le seul moyen de recueillir des données, mais aussi l'observation directe pendant près de deux jours dans chaque entreprise industrielle et quelques heures pour les entreprises commerciales dont les propriétaires acceptent de partager dans le questionnaire. Une feuille Excel a été conçu pour l'analyse des données recueillies et d'obtenir les tableaux représentés. Enfin, les résultats du questionnaire ont été analysées afin de déterminer les principales causes de difficulté d'appliquer les techniques d'IE dans les PME.

MOTS CLÉS: techniques de IE, petites et moyennes entreprises, la prévision de la demande, la planification des installations, le transport, l'étude la méthode, la mesure du travail, planification de la production et le contrôle, contrôle qualité, et de la maintenance

* Received: 8/6/2011, Accepted: 10/7/2011 (Review Paper)

+ Contact Author (ashour_eng@hotmail.com) 


\section{INTRODUCTION}

Economic experts and policy makers have argued that the private sector and in particular small and medium-sized enterprises is the engine for economic development in both developed and developing countries. The 21 member Asia-Pacific Economic Corporation (APEC) survey on SMEs [1] revealed that SMEs play a major economic role in all of the APEC member economies especially as it relates to job creation, SMEs make up over 90 percent of enterprises and over 32 to 84 percent of the employment in individual economies. Wennekers and Thurik [2] indicate that there is extensive evidence from the 1970s and 1980s onwards, economic activity has moved away from large firms to small firms. Studies conducted by Acs and Audretsch [3] and Carlsson [4] provide an overview of the evidence concerning the manufacturing industry in a number of countries at varying stages of their economic development. They also provide reasons for the shift from large to small firms. Carlsson suggest two explanations for this shift. The first one was attributed to the fundamental changes occurring in the world economy since the 1970s. These changes relate to the intensification of global competition, an increase in the degree of uncertainty, and growth in market fragmentation. Whereas, the second reason was due to the changes in the character of technological progress. Winston Dawes [5], indicate that policy makers should focus on fostering linkage between large and small firms focusing on specific industries or clusters and enhancing entrepreneurship, through an efficient patent registration system, less regulation and more economic freedom. Small firms are important because most new firms start out small. However, SMES more than just jobs, job growth

and income to participants. They also assist with the social landscape as larger companies and the government can't provide all the employment and social benefits in the economy. SMES allow people from different backgrounds to participate in the gains of the economy without having to wait for large company to intervene.
Profile of SMEs in Egypt [6], indicate that it is becoming increasingly apparent to governments and policy makers that the role of small and medium enterprises (M/SMEs) is crucial to the development and growth of any given economy. According to the Arab Human Development Report, $90 \%$ of the Arab economy depends on M/SMEs. In Egypt, 99\% of the non-agricultural companies are M/SMEs, constituting $80 \%$ of the companies in the private sector and cash for $66 \%$ of the whole of the labor of the country. The development of M/SMEs is thus a priority for any government that would like to ensure its economic development. According to expert group meeting on harnessing technology for enhanced small and medium sized enterprises productivity and competitiveness [7], There are three key players who are responsible for influencing the capacity of SMEs to access, incorporate,

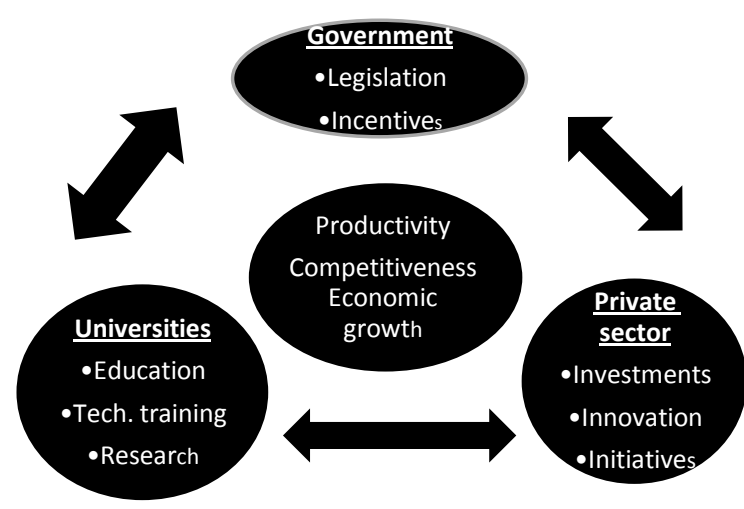

Fig.1. Relation between the three responsible key players

harness, and develop new technologies towards improving their productivity and competitiveness: Government sectors including national research centers, private sector, including SMEs and associated business support organizations and services providers, and universities and technical institutes, (see Fig.1). 
The Small and Medium Enterprise Policy Development Project (SMEPoL)[8] began operations in June 2000 with an agreement of collaboration between the Canadian International Development Agency (CIDA) and the International Development Research Centre (IDRC) - the Canadian Executing Agency and partner for the project. As of July 2004, SMEPoL focused its efforts on supporting the Ministry of Finance (MOF) in short term policy development, as well as a concerted long term plan to enhance the environment to increase M/SMEs' potential to grow. In this context, and as part of the project's efforts to raise awareness of and provide information on the M/SME sector, the document entitled "Profile of M/SMEs in Egypt" was published in March 2003. The profile's aim is to serve as an essential tool to assist policymakers, scholars and practitioners by answering key questions on the role and impact of the M/SME sector in Egypt.

\section{2-SMALL AND MEDIUM ENTERPRISES CHARACTERISTICS AND DEFINITION}

Small and medium-sized enterprises (SMEs) operate in the formal sector of the economy, employ wage-earning workers, and participate more fully in organized markets. SMEs are seen as a major engine of upward social mobility through the creation of employment opportunities at increasing wages, pulling in people from ower-productivity occupations. Hallberg [9], notes that SMEs are very diverse group; they include diverse variety of firms-village handicraft makers, small machine shops, restaurants and computer software firms - that range in sophistication and skill and operate in very different markets and social environments. Collins and porras [10], argue the lack of a "vision framework," which must include (1) core values and beliefs (2) purpose (3) mission, causes the failure of small enterprises. Walls [11], points out two major causes: (1) managerial incompetence and (2) unbalanced technical exper- tise. Zimmerer and Scarborough [12], blame the SMES failures on their limited resources, inexperienced management, and the lack of financial stability. They state that these main causes are why small business has a mortality rate significantly higher than their larger counterparts (less than 50 percent surviving after 4 years of existence).

SMEs are known to operate in different markets such as urban, rural, local, national, regional, and international. They also embody different skills, capital, sophistication, and growth orientation. SMEs tends to have a more flexible management and labour structures, which can allow for easier networking and exchange between units and opportunities for innovation. There is no universal statistical definition of SMEs as it varies from country to country. This reflection of the significant difference in aggregate income and its distribution in production structure and capabilities, and the industrial technological characteristics among economies.

In Egypt, according to "Profile of SMEs in Egypte [6]", there are many different specifications used by various institutions. So, comparability preferences are almost unattainable. Specifications are based on the number of employees, the capital, or on the annual sales. For example Table 1 shows the specifications for SMES based on number of employees.

Table 1 Specifications for SMEs based on number of employees

\begin{tabular}{|c|c|c|c|c|}
\hline \multirow{2}{*}{ Sector } & \multicolumn{4}{|c|}{ Number of Employees } \\
\cline { 2 - 5 } & Micro & Small & Medium & Large \\
\hline Trade & $1-4$ & $5-9$ & $10-19$ & $20+$ \\
\hline Service & $1-4$ & $5-9$ & $10-19$ & $20+$ \\
\hline $\begin{array}{c}\text { Manufac- } \\
\text { turing }\end{array}$ & $1-4$ & $5-49$ & $50-99$ & $100+$ \\
\hline $\begin{array}{c}\text { Construc- } \\
\text { tion }\end{array}$ & $1-4$ & $5-49$ & $50-99$ & $100+$ \\
\hline
\end{tabular}

Other Organizations in Egypt use different specifications as shown in Table 2. 
Table 2. Specifications used by other organizations in Egypt

\begin{tabular}{|c|c|}
\hline AUTHORITY & MSME-DEFINITION \\
\hline Ministry of Industry & $\begin{array}{c}10-100 \text { workers } \\
0-500000 \text { EGP Fixed } \\
\text { Assets }\end{array}$ \\
\hline Ministry of Planning & $\begin{array}{l}0-50,000 \text { in fixed assets } \\
\text { including land and build- } \\
\text { ings. }\end{array}$ \\
\hline $\begin{array}{l}\text { Ministry of Rural } \\
\text { Development }\end{array}$ & $\begin{array}{l}\text { Definition does not use } \\
\text { economic criteria }\end{array}$ \\
\hline $\begin{array}{l}\text { Institute for National } \\
\text { Planning }\end{array}$ & $10-49$ workers \\
\hline $\begin{array}{l}\text { Central Agency for Public } \\
\text { Mobilization and Statistics }\end{array}$ & $50-100$ workers. \\
\hline $\begin{array}{c}\text { Industrial Development } \\
\text { Bank: }\end{array}$ & $\begin{array}{l}\text { Uses value of fixed assets, } \\
\text { adjusted periodically. }\end{array}$ \\
\hline $\begin{array}{l}\text { Credit Guarantees } \\
\text { Corporation (CGC) }\end{array}$ & $\begin{array}{l}\text { EGP } 40,000 \text { - EGP } 7 \text { mil- } \\
\text { lion of Assets (excluding } \\
\text { land and buildings); } 1 \text { to } 5 \\
\text { resp. } 6 \text { workers }\end{array}$ \\
\hline $\begin{array}{l}\text { USAID: } \\
\text { For National Bank For } \\
\text { Development(NBD) For } \\
\text { Business Associations }\end{array}$ & $\begin{array}{l}\text { 0- } 15 \text { workers } 0-25,000 \\
\text { Fixed Assets } \\
\text { Micro: (1-5) Employees } \\
\text { Small: }(6-15) \text { employees }\end{array}$ \\
\hline
\end{tabular}

Specifications may concern with type of industry as in Table 3

Table 3.specifications according to type of industry of SMES

\begin{tabular}{|c|c|}
\hline Size of enterprises & Defining criteria \\
\hline & $5-49$ employees \\
Small & $25,000-5,000,000$ LE in \\
(Manufacturing) & $\begin{array}{c}\text { capital } 100,000-10,000,000 \\
\text { LE in annual sales }\end{array}$ \\
\hline Small & $5-9$ employees \\
& $25,000-500,000$ LE in capi- \\
tal $100,000-$ \\
(Services \& Trade) \\
& 5000,000 LE in annual sales \\
\hline Medium & $5,000,000-10,000,000$ in \\
(Manufactur- & capital 10,000,000- \\
ing) & $20,000,000$ in annual sales \\
\hline Medium & $10-19$ employees \\
(Services \& & $500,000-2,000,000$ LE in \\
Trade) & capital \\
\hline
\end{tabular}

So there is no unified specification of M/SMEs that can be adopted nationally in Egypt.

\section{3-NUMBER OF M/SMES OPERATING IN EGYPT}

According to the Central Agency for Public Mobilization and Statistics (CAPMAS) establishment, the number of M/SMEs operating in
Egypt operating in the trade, services, manufacturing, and construction sectors establishments are 1,641,791, as illustrated in Table 4.

Table 4.Number of M/SMEs operating in Egypt

\begin{tabular}{|c|c|c|c|c|c|}
\hline $\begin{array}{l}\text { Sec- } \\
\text { tor/size } \\
\text { (by no. } \\
\text { of } \\
\text { workers) }\end{array}$ & $\begin{array}{l}\text { Micro } \\
(1-4)\end{array}$ & $\begin{array}{l}\text { Small } \\
(5-9)\end{array}$ & $\begin{array}{c}\text { Me- } \\
\text { dium } \\
(10- \\
19)\end{array}$ & $\begin{array}{l}\text { Large } \\
(20+)\end{array}$ & Total \\
\hline Trade & 898637 & 27199 & 4253 & 1678 & 31767 \\
\hline $\begin{array}{l}\text { Servic- } \\
\text { es }\end{array}$ & 396748 & 21060 & 4584 & 3199 & 25591 \\
\hline $\begin{array}{l}\text { Sector/ } \\
\text { size }\end{array}$ & $\begin{array}{l}\text { Micro } \\
(1-4)\end{array}$ & $\begin{array}{l}\text { Small } \\
(5-49)\end{array}$ & $\begin{array}{c}\text { Me- } \\
\text { dium } \\
(50- \\
99)\end{array}$ & $\begin{array}{c}\text { Large } \\
(100+ \\
)\end{array}$ & Total \\
\hline $\begin{array}{l}\text { Manu- } \\
\text { factur- } \\
\text { ing }\end{array}$ & 233845 & 43315 & 859 & 732 & 78751 \\
\hline $\begin{array}{l}\text { Con- } \\
\text { struc- } \\
\text { tion }\end{array}$ & 8881 & 2328 & 82 & 48 & 11339 \\
\hline total & $\begin{array}{c}153811 \\
1\end{array}$ & 93902 & 9778 & 5657 & 47448 \\
\hline
\end{tabular}

Those M/SMEs comprise 99.7 percent of the total establishments in Egypt. Trade appears to be the most important economic sector among microenterprises, since 58 percent of them engage in trade related activities, while 26 percent work in the services field. This composition varies if we look at small enterprises, where manufacturing represent 46 percent of their business, followed by trade at 29 percent and services at 22 percent. In medium sized businesses, services and trade sectors have almost equal weights of 46 percent, and 43 percent, respectively.

A study conducted by the International Finance Corporation (IFC) entitled "the SMEs landscape in Egypt" suggests that the number of M/SMEs in Egypt in 2003 accounted for 2,576,937 enterprises. Similar to this report's projection, the IFC study used 
the 1986 and 1996 CAPMAS Establishment Censuses as the base for its projections. However the report suggested an aggregate growth rate for all governorates which accounted for 7 percent on an annualized basis (a less conservative rate than the one extrapolated for this profile, which varies between 1.06 and 1.25 percent according to governorate).

\section{4-PERFORMANCE MEASUREMENTS IN SMALL AND MEDIUM-SIZED ENTER- PRISES}

The introduction of Performance Measurement Systems (PMS) in small and medium sized enterprises is still a field in which little research has been conducted yet. For the past 30 years, these both areas of research have already separately been looked into by scholars, which are now being acknowledged by the numerous publications, especially within the area of performance measurement (Neely, [13]). Until now, empirical and theoretical studies in performance measurement in SMEs have not been known very well, which can be noted in the lack of publications when comparing both individual topics on their own (Garengo et al., [14]), Nevertheless further studies highlights that there is still a gap between this knowledge and its use in practice (Garengo et al. [15]; Evans [16]; and smith [17]). Bititci et al. [18] formulated the additional criticism that the involved managers know what needs to be measured at the end of the management process, but the question remains open as to how this system can be successfully implemented. In recent years it has become more apparent that the complexity increases in manufacturing SMEs, which requires a different management culture and rationalization (Martins and Salerno [19]).

Alexandre Berm [20], raise that not all companies, especially SMEs, can develop and implement a performance measurement system following the traditional process. Its rather necessary for those companies to consult an external person or organization in a preceding stage in order to check the corporate ability for a successful implementation and later use.

\section{5- INDUSTRIAL ENGINEERING TECH- NIQUES CONCERNING PRODUCTIVITY MANAGEMENT}

Industrial engineering techniques are considered as scientific management. Industrial engineering is concerned with the design, improvement, and installation of integrated systems people, materials, information, equipment, and energy. It draws upon specialized knowledge and skill in mathematical, physical and social sciences together with the principle and methods of engineering analysis and design to specify, predict and evaluate the results to be obtained from such systems. Therefore IE techniques are those techniques to be applied in designing, operating, and improving the systems. Systems are designed in two levels, as shown in Fig.2.

The first one is human activity level. It contains manufacturing process itself, (or the processing procedure of a service organization), materials and all other resources utilized in the production process, machines and equipment, methods by Which workers perform tasks, layout of facilities and specification of material flow, material handling equipment and procedures, work place design, storage information, equipment, and energy, data recording procedures for management reporting, procedures for maintenance planning, and safety procedures methods of engineering analysis and design to specify, predict, and evaluate the results to be obtained from such systems.

The second one is management control level.

It contains, management planning systems, forecasting procedures, budgeting and economic analysis, wage and salary planes, Incentive plans and other employee relations systems, Recruiting, training, and placement of employee, materials requirement planning, Inventory control procedures, production scheduling, dispatching, progress and status reporting, corrective action procedures, overall information system, quality control system, cost 
control and reduction, resource allocation, organization design, decision support systems.

\section{6-SAMPLE DESCRIPTIONS}

A sample of 100 manufacturing, and trade industry business was selected from biggest industrial regions in Egypt such as $10^{\text {th }}$ of Ramadan. $6^{\text {th }}$ of October and el Oboor cities on the basis of location, industry grouping and size of company. The list of SMES was obtained from the relevant chambers of commerce using commercially data base published by each of the three regional councils the majority of business selected employed less than 100 people. A total of 81 questionnaires were analyzed, represent $81 \%$ of the identified population exploratory research is aimed at looking at the use of IE techniques in SMES as there appears to be very few studies done on this topic in a regional area. the importance of this study is to identify the percentage of applicability of IE techniques in SMES if they applicable, if not, it was tried to determine the reasons for why these techniques are not applicable in this sector. The following table represents the selected numbers for each type of enterprises and whether it's small or medium in Table 5.

Table 5 classification of SMES used in questionnaire

\begin{tabular}{|c|c|c|c|}
\hline $\begin{array}{c}\text { Type of Enter- } \\
\text { prise }\end{array}$ & Industrial & Trade & Total \\
\hline SMALL & 10 & 20 & 30 \\
\hline MEDIUM & 43 & 8 & 51 \\
\hline Total & 53 & 28 & 81 \\
\hline
\end{tabular}

According to size of the enterprise it's about $37 \%$ represent small enterprises and 63\% represent medium enterprises but due to the type of enterprise about $65.4 \%$ are industrial and about $34.6 \%$ are trades.

\section{7- EXTENT OF APPLICATION OF IE TECHNIQUES}

The data will be analyzed using the following concept. First a comparison will be made between the small industrial enterprises and the medium industrial enterprises. Then another comparison will be made between small trade enterprises and medium trade enterprises. The comparisons will be represented in percent of applicability for each technique of IE techniques.

The results are given in the following tables:

Table 6.Questionnaire results for demand forecasting

\begin{tabular}{|c|c|c|c|c|}
\hline & \multicolumn{2}{|c|}{$\begin{array}{c}\text { Small } \\
\text { enterprises }\end{array}$} & \multicolumn{2}{c|}{$\begin{array}{c}\text { Medium } \\
\text { enterprises }\end{array}$} \\
\hline & $\begin{array}{c}\text { Indus- } \\
\text { trial }\end{array}$ & Trade & $\begin{array}{c}\text { Indus- } \\
\text { trial }\end{array}$ & Trade \\
\hline $\begin{array}{c}\text { Depending } \\
\text { on the } \\
\text { discretion }\end{array}$ & $100 \%$ & $60 \%$ & $83.33 \%$ & $11.11 \%$ \\
\hline $\begin{array}{c}\text { Application } \\
\text { of } \\
\text { mathemati- } \\
\text { cal methods }\end{array}$ & $0 \%$ & $0 \%$ & $4.76 \%$ & $0 \%$ \\
\hline $\begin{array}{c}\text { Ready to use } \\
\text { programs }\end{array}$ & $0 \%$ & $40 \%$ & $11.9 \%$ & 88.89 \\
\hline Others & $0 \%$ & $0 \%$ & $0 \%$ & $0 \%$ \\
\hline
\end{tabular}

Table 7.Questionnaire results for facility planning

\begin{tabular}{|c|c|c|c|c|}
\hline & \multicolumn{2}{|c|}{$\begin{array}{c}\text { Small } \\
\text { enterprises }\end{array}$} & \multicolumn{2}{c|}{$\begin{array}{c}\text { Medium } \\
\text { enterprises }\end{array}$} \\
\hline $\begin{array}{c}\text { Depending } \\
\text { on the } \\
\text { possibilities }\end{array}$ & $70 \%$ & $15 \%$ & $7.14 \%$ & $0 \%$ \\
\hline $\begin{array}{c}\text { Industri- } \\
\text { kets neare mar- }\end{array}$ & $30 \%$ & $85 \%$ & $47.62 \%$ & $88.89 \%$ \\
\hline $\begin{array}{c}\text { The } \\
\text { presence of } \\
\text { sources close to } \\
\text { the supply of raw } \\
\text { materials }\end{array}$ & $0 \%$ & $0 \%$ & $14.29 \%$ & $0 \%$ \\
\hline $\begin{array}{c}\text { Near the facility } \\
\text { of the wherea- } \\
\text { bouts of the } \\
\text { labor required }\end{array}$ & $0 \%$ & $0 \%$ & $33.33 \%$ & $11.11 \%$ \\
\hline $\begin{array}{c}\text { Reduce the cost } \\
\text { of transport }\end{array}$ & $0 \%$ & $0 \%$ & $2.38 \%$ & $0 \%$ \\
\hline $\begin{array}{c}\text { Others } \\
\text { Otherial }\end{array}$ & $0 \%$ & $0 \%$ & $0 \%$ & $0 \%$ \\
\hline
\end{tabular}




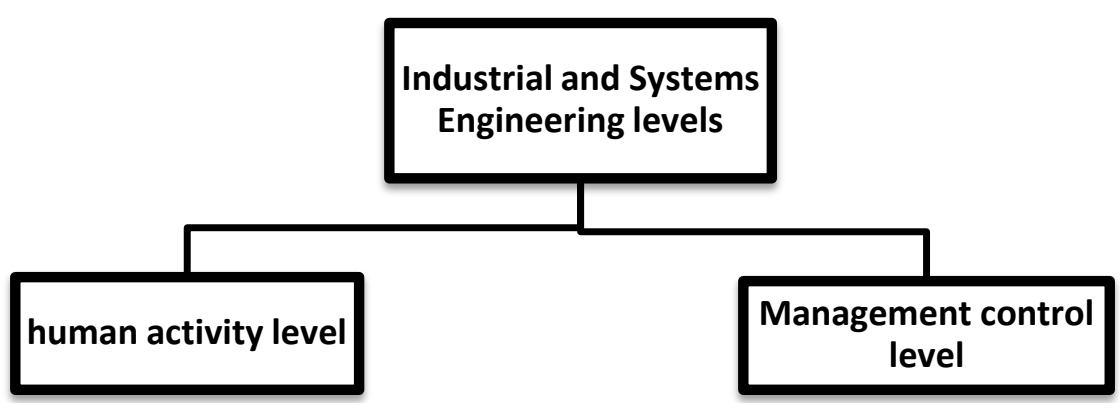

*Manufacturing process itself, (or the processi procedure of a service organization).

* Materials and all other resources utilized in t production process.

*Machines and equipment, methods by whi workers perform tasks.

*Layout of facilities and specification of mater flow.

*Material handling equipment and procedur *Work place design.

*Storage information.

*Data recording procedures for management reporting.

*Procedures for maintenance planning.

*Safety procedures methods of engineering an ysis and design to specify.

*Predict, and evaluate the results to be obtain from such systems.
*Management planning systems.

*Forecasting procedures.

*Budgeting and economic anal sis.

*Other employee relations systems.

*Recruiting, training, and placeme of employee.

* Materials requirement planning.

*Inventory control procedures.

*Production scheduling, dispatchir progress and status reporting.

*Corrective action procedures.

*Overall information system.

*Quality control system.

*Cost control and reduction.

*Resource allocation, organization design.

*Decision support systems.

Fig.2. Industrial and systems engineering levels 
Table 8.Questionnaire results for transportation

\begin{tabular}{|c|c|c|c|c|}
\hline & \multicolumn{2}{|c|}{$\begin{array}{c}\text { Small } \\
\text { enterprises }\end{array}$} & \multicolumn{2}{|c|}{$\begin{array}{c}\text { Medium } \\
\text { enterprises }\end{array}$} \\
\hline & $\begin{array}{l}\text { Indu } \\
\text { strial }\end{array}$ & $\begin{array}{c}\text { Trad } \\
\mathrm{e}\end{array}$ & $\begin{array}{l}\text { Indu } \\
\text { strial }\end{array}$ & Trade \\
\hline $\begin{array}{l}\text { Company is not } \\
\text { responsible for the } \\
\text { distribution }\end{array}$ & $30 \%$ & $\begin{array}{c}100 \\
\%\end{array}$ & $\begin{array}{c}35.7 \\
1 \%\end{array}$ & $77.78 \%$ \\
\hline $\begin{array}{l}\text { Transport random } \\
\text { manner }\end{array}$ & $30 \%$ & $0 \%$ & $\begin{array}{c}2.38 \\
\%\end{array}$ & $11.11 \%$ \\
\hline $\begin{array}{c}\text { Using a } \\
\text { mathematical } \\
\text { method to deter- } \\
\text { mine the trip } \\
\text { Transport }\end{array}$ & $0 \%$ & $0 \%$ & $\begin{array}{c}2.38 \\
\%\end{array}$ & $0 \%$ \\
\hline $\begin{array}{l}\text { According to the } \\
\text { importance of the } \\
\text { client and its prox- } \\
\text { imity to the place } \\
\text { of manufacture }\end{array}$ & $0 \%$ & $0 \%$ & $\begin{array}{c}26.1 \\
9 \%\end{array}$ & $0 \%$ \\
\hline $\begin{array}{l}\text { According to the } \\
\text { priorities of the } \\
\text { demand for the } \\
\text { product } \\
\text { from } \\
\text { customer }\end{array}$ & $40 \%$ & $0 \%$ & $\begin{array}{l}33.3 \\
3 \%\end{array}$ & $11.11 \%$ \\
\hline Others & $0 \%$ & $0 \%$ & $0 \%$ & $0 \%$ \\
\hline
\end{tabular}

Table 9.Questionnaire results for method study recording the production method

\begin{tabular}{|c|c|c|}
\hline & $\begin{array}{c}\text { Small } \\
\text { enterprises }\end{array}$ & $\begin{array}{l}\text { Me- } \\
\text { dium } \\
\text { enter- } \\
\text { prises }\end{array}$ \\
\hline $\begin{array}{c}\text { By a map showing the } \\
\text { sequence of production }\end{array}$ & $0 \%$ & $\begin{array}{l}\text { Indu- } \\
\text { strial }\end{array}$ \\
\hline $\begin{array}{c}\text { There is no way to } \\
\text { register (how produc- } \\
\text { tion are known to all) }\end{array}$ & $70 \%$ & $30.95 \%$ \\
\hline $\begin{array}{c}\text { Through schemes run } \\
\text { from the suppliers of } \\
\text { machinery }\end{array}$ & $10 \%$ & $26.19 \%$ \\
\hline $\begin{array}{c}\text { Through schemes run } \\
\text { by the requests of the } \\
\text { product }\end{array}$ & $20 \%$ & $30.95 \%$ \\
\hline $\begin{array}{c}\text { There is no fixed } \\
\text { sequence of production } \\
\text { due to instability of } \\
\text { products }\end{array}$ & $0 \%$ & $0 \%$ \\
\hline
\end{tabular}

Table 10.Questionnaire results for method study developing of production method

\begin{tabular}{|c|c|c|}
\hline & $\begin{array}{c}\text { Small } \\
\text { enterprises }\end{array}$ & $\begin{array}{c}\text { Medium } \\
\text { enterprises }\end{array}$ \\
\hline $\begin{array}{c}\text { There are plans to } \\
\text { update and replace } \\
\text { the work of ma- } \\
\text { chines and conti- } \\
\text { nuous training for } \\
\text { workers depending } \\
\text { on the client's re- } \\
\text { quest }\end{array}$ & $0 \%$ & Industrial \\
\hline $\begin{array}{c}\text { There are no ways } \\
\text { to }\end{array}$ & $100 \%$ & $14.29 \%$ \\
\hline
\end{tabular}

Table 11. Questionnaire results for method study determining the standard time

\begin{tabular}{|c|c|c|}
\hline & $\begin{array}{c}\text { Small } \\
\text { enterprises }\end{array}$ & $\begin{array}{l}\text { Medium } \\
\text { enterprises }\end{array}$ \\
\hline & Industrial & Industrial \\
\hline $\begin{array}{l}\text { Does not deter- } \\
\text { mine the stan- } \\
\text { dard time }\end{array}$ & $100 \%$ & $85.71 \%$ \\
\hline $\begin{array}{l}\text { There is no } \\
\text { practical way (to } \\
\text { be } \\
\text { determined by } \\
\text { experience) }\end{array}$ & $0 \%$ & $7.14 \%$ \\
\hline $\begin{array}{l}\text { Through the } \\
\text { specification of } \\
\text { the machine }\end{array}$ & $0 \%$ & $7.14 \%$ \\
\hline
\end{tabular}

Table 12. Questionnaire results for method study determining the effective and ineffective time

\begin{tabular}{|c|c|c|}
\hline & $\begin{array}{c}\text { Small } \\
\text { enterprises }\end{array}$ & $\begin{array}{c}\text { Medium } \\
\text { enterprises }\end{array}$ \\
\hline $\begin{array}{c}\text { There is no } \\
\text { inefficient time } \\
\text { (given that a sim- } \\
\text { ple }\end{array}$ & $0 \%$ & Industrial \\
$\begin{array}{c}\text { Human interven- } \\
\text { tion) } \quad\end{array}$ & $100 \%$ & $8.76 \%$ \\
\hline $\begin{array}{c}\text { Not to be } \\
\text { determined }\end{array}$ & $0 \%$ & $9.52 \%$ \\
\hline $\begin{array}{c}\text { To be determined } \\
\text { in accordance } \\
\text { with the prior } \\
\text { plans }\end{array}$ & & \\
\hline
\end{tabular}


Table 13.Questionnaire results for production planning

\begin{tabular}{|c|c|c|}
\hline & $\begin{array}{c}\text { Small } \\
\text { enterprises }\end{array}$ & $\begin{array}{c}\text { Medium } \\
\text { enterprises }\end{array}$ \\
\hline & Industrial & Industrial \\
\hline $\begin{array}{l}\text { Determined according } \\
\text { to market demand }\end{array}$ & $10 \%$ & $14.29 \%$ \\
\hline $\begin{array}{l}\text { Determined according } \\
\text { to financial resources }\end{array}$ & $30 \%$ & $28.57 \%$ \\
\hline $\begin{array}{l}\text { The volume of produc- } \\
\text { tion is fixed according } \\
\text { to productive capacity }\end{array}$ & $0 \%$ & $11.9 \%$ \\
\hline $\begin{array}{l}\text { Determined depending } \\
\text { on the discretion }\end{array}$ & $20 \%$ & $11.9 \%$ \\
\hline $\begin{array}{l}\text { Working by order not } \\
\text { by continuous produc- } \\
\text { tion }\end{array}$ & $40 \%$ & $33.33 \%$ \\
\hline Others & $0 \%$ & $0 \%$ \\
\hline
\end{tabular}

Table 15. Questionnaire results for action planning to control the Storage

\begin{tabular}{|c|c|c|}
\hline & $\begin{array}{c}\text { Small } \\
\text { enterprises }\end{array}$ & $\begin{array}{c}\text { Medium } \\
\text { enterprises }\end{array}$ \\
\hline $\begin{array}{c}\text { Determine the minimum } \\
\text { for each part depending on } \\
\text { the size of the demand }\end{array}$ & $0 \%$ & Industrial \\
\hline $\begin{array}{c}\text { Providing raw materials } \\
\text { for a fixed time period }\end{array}$ & $90 \%$ & $71.43 \%$ \\
\hline $\begin{array}{c}\text { Providing raw materials } \\
\text { depending on the } \\
\text { financial possibilities }\end{array}$ & $10 \%$ & $26.19 \%$ \\
\hline Others & $0 \%$ & $0 \%$ \\
\hline
\end{tabular}

Table 14. Questionnaire results for Future planning to make amendments to the sources of raw materials

\begin{tabular}{|c|c|c|}
\hline & $\begin{array}{c}\text { Small } \\
\text { enterprises }\end{array}$ & $\begin{array}{c}\text { Medium } \\
\text { enterprises }\end{array}$ \\
\hline & Industrial & Industrial \\
\hline There are no future plans & $100 \%$ & $80.95 \%$ \\
\hline There are future plans & $0 \%$ & $19.05 \%$ \\
\hline Others & $0 \%$ & $0 \%$ \\
\hline
\end{tabular}

Table 16.Questionnaire results for maintenance

\begin{tabular}{|c|c|c|c|c|c|c|c|}
\hline & \multicolumn{3}{|c|}{$\begin{array}{l}\text { Priority of implementation of the maintenance of the } \\
\text { defective parts }\end{array}$} & \multicolumn{2}{|c|}{ Items of maintenance work } & \multicolumn{2}{|c|}{$\begin{array}{l}\text { Commitment toimple- } \\
\text { mentation }\end{array}$} \\
\hline item & $\begin{array}{l}\text { Affected by } \\
\text { amount of } \\
\text { production }\end{array}$ & $\begin{array}{c}\text { Affected by the } \\
\text { quality of the } \\
\text { project }\end{array}$ & $\begin{array}{l}\text { Availability } \\
\text { of spare parts }\end{array}$ & $\begin{array}{l}\text { According to } \\
\text { catalogs }\end{array}$ & $\begin{array}{l}\text { By expe- } \\
\text { rience }\end{array}$ & $\begin{array}{l}\text { Not regu- } \\
\text { larly }\end{array}$ & regularly \\
\hline small & $80 \%$ & $20 \%$ & $0.0 \%$ & $0.0 \%$ & $100 \%$ & $90 \%$ & $10 \%$ \\
\hline $\begin{array}{l}\text { me- } \\
\text { dium }\end{array}$ & $39.53 \%$ & $9.3 \%$ & $51.16 \%$ & $4.65 \%$ & $95.35 \%$ & $69.77 \%$ & $30.23 \%$ \\
\hline
\end{tabular}

Table 17.Questionnaire results for quality control defining quality standards

\begin{tabular}{|c|c|c|}
\hline & $\begin{array}{c}\text { Small } \\
\text { enterprises }\end{array}$ & $\begin{array}{c}\text { Medium } \\
\text { enterprises }\end{array}$ \\
\hline $\begin{array}{c}\text { Not specify the } \\
\text { criteria for } \\
\text { quality }\end{array}$ & Industrial & Industrial \\
\hline $\begin{array}{c}\text { The use of } \\
\text { statistical methods and the } \\
\text { maps in the quality control }\end{array}$ & $30 \%$ & $25.58 \%$ \\
\hline $\begin{array}{c}\text { Meet the } \\
\text { requirements of customers in } \\
\text { the product }\end{array}$ & $0 \%$ & $34.88 \%$ \\
\hline $\begin{array}{c}\text { Determine defects and errors } \\
\text { for } \\
\text { each process by } \\
\text { appropriate } \\
\text { measurement } \\
\text { devices }\end{array}$ & $30 \%$ & $39.53 \%$ \\
\hline \multirow{2}{*}{\begin{tabular}{l} 
\\
\hline
\end{tabular}} & $30 \%$ & \\
\hline
\end{tabular}

Table 18.Questionnaire results for quality control followed by quality assurance

\begin{tabular}{|c|c|c|}
\hline & $\begin{array}{c}\text { Small } \\
\text { enterprises }\end{array}$ & $\begin{array}{c}\text { Medium } \\
\text { enterprises }\end{array}$ \\
\hline $\begin{array}{c}\text { Industrial } \\
\text { ty } \\
\text { assurance }\end{array}$ & $100 \%$ & $88.1 \%$ \\
\hline $\begin{array}{c}\text { There are no tools for quali- } \\
\text { measures to avoid any } \\
\text { quality problems }\end{array}$ & $0 \%$ & $0 \%$ \\
\hline $\begin{array}{c}\text { Selection and } \\
\text { training of } \\
\text { personnel to ensure the } \\
\text { right person in the right } \\
\text { place }\end{array}$ & $0 \%$ & $11.9 \%$ \\
\hline $\begin{array}{c}\text { Measure the performance of } \\
\text { each } \\
\text { element of the work }\end{array}$ & $0 \%$ & $0 \%$ \\
\hline $\begin{array}{c}\text { Quality staff has a role in } \\
\text { solving }\end{array}$ & $0 \%$ & $0 \%$ \\
\hline technical problems & $0 \%$ & $0 \%$ \\
\hline Others & & \\
\hline
\end{tabular}




\section{CONCLUSIONS}

From the previous analysis, one can conclude that there are several problems faced those small- and mediumsize enterprises and that may lead to disruption of the application of industrial engineering techniques. These problems are divided into three categories as follows:

\subsection{Problems Associated With Input}

\section{(a) Lack of Infrastructure for the} Personal Project Itself

This can be divided to the following points: Lack of marketing expertise, limited expertise, lack of management skills, lack of skills in accounting, inability to extrapolate the variables, and reservation or very severe eruption.

\section{(b) Insufficient of Equipment}

This can be divided to the following points: Availability of equipment specifications, operation of limited possibilities, and poor technical equipment.

\section{(c) Poor Raw Material Specifications} and lor An Increase in the Cost of Providing.

\section{(d) Inadequate Project Site}

This can be summarized in the following points: Poor geographical location of the project, inadequate size of the site, poor internal planning, and lack of appropriate environmental site conditions.

\section{(e) Problems Related to Employment}

This problem can take several forms such as low levels of expertise of the employment, high wage employment, and the high rate of labor turnover.

\section{(f) Lack of Financial Capacity}

This may take the following forms: The weakness of the working capital, the occupation of the financial structure, and lack of capacity to add the necessary investments.

\subsection{Problems Associated with Operations}

(a) Design of processes: Most of the projects do not have the specifications of the product and therefore flawed from the outset and there are no uniform drawings or descriptions.

\section{(b) Operations and Production Processes}

They are relying on the personal experience of the operator or his supervisor, which may vary from person to another. There are no rules and standard operating instructions for the commitment of all workers so there is a fluctuate behavior of quality standards.

\section{(c) Quality Control Processes}

There are specific instructions and methods for inspection of production and quality control, for raw materials and in all stages of production. But there is no quality control for the final product.

\section{(d) Transportation and Circulation}

These processes have a direct impact on production rates and quality standards. However most of SMES 
do not follow the proper ways to transport the product.

\section{(e) Maintenance Operations}

Lack of proper maintenance concepts leads to inability to deal with the sudden malfunction. it is one of the most common problems in SMES.

\subsection{Problems Associated with Outputs}

These are the high similarity of the products with products of similar projects, high product prices, and low-quality.

\section{REFERENCES}

1) APEC (1994), "The APEC Survey on Small and Medium Enterprises", Coordinating Agency, Medium and Small Business Administration, Ministry of Economic Affairs, Chinese Taipei.

2) Wennekers,s., and Thurik, R.,(1999), Linking Entrepreneurship and Economic Growth, "Small Business Economics, 13,PP.27-55.

3) ACS, Z.J.,(1996),"Small Firms and Economic Growth" , in P.H. Admiral ed Small Business in the Modern Economy, Oxford, UK: Blackwell Publishers.

4) Carlsson,B., (1992),"The Rise of Small Business: Causes and Consequences" , In W.J.Adams ed., Singular Europe, Economy and Policy Of The European Community after 1992, Ann Arbor, MI: University of Michigan press, PP.145-169.

5) Winston, D., (2005), the Economic Impact of Small and Medium-Sized Enterprises (SMES).

6) Profile of SMEs in Egypt 2005.
7) Expert Group Meeting on Harnessing Technology for Enhanced Small and Medium Sized Enterprises Productivity and Competitiveness (November 2007).

8) The Small and Medium Enterprise Policy Development Project (SMEPoL)

9) Helberg, K., (2001)," A Market Oriented Strategy For Small and Medium Scale Enterprises" , IFC discussion paper, NO. 40.

10) Collins, J.C. and J.I. Porras "Organizational Vision and Visionary Organizations," California Management Review, fall 1991, PP.30-52.

11) Walla, W.A.(1993). Working Knowledge: What You Need to Know Before Opening a Business, Echlon Publishing CO., Cincnnati, $\mathrm{OH}$.

12) Zimmerer, T.W. and N.M. Scarborough (1998). Essential of Entrepreneurship and Small Business Management, Second Edition, Prentice Hall, Upper Saddle river, NJ.

13) Nelly, A.D (1999)" The Performance Measurement Revolution: Why Now and Where Next?" International Journal of Operations \& Production Management, Vol.19.No. 2, PP.205-208.

14) Garengo, P., Biazzo, S. and Bititchi, U.S. (2005) "Performance Measurement System in SMES", International Journal of Management Reviews, Vol.8, No. 3, PP.175-190.

15) Evans, J.R. (2004) "An Exploratory Study of Performance Measurement Systems and Relationships with Performance Results" Journal of Operations Management, Vol.22, No .3, PP.219-232.

16) Smith, M.H. and Smith, D. (2006) Implementing Strategically Aligned Performance Measurement in Small Firms, Vol. 106, PP.393-408. 
17) Bititci, U.S., Turner, T. and Ball, P.D. (1999) "The Viable Business Structure for Managing Agility "International Journal of Agile Management Systems, Vol.1, PP.190199.

18) Martins, R.A. and Salerno, M.S (1999) "Use of New Performance Measurement System, Some Empirical Findings", Managing Operations Networks- VI International EurOMA conference, Venice, Italy,7-8 June.

19) Alexandre Berm, (2008) "Performance Measurement in SMES" International Journal of Globalization and Small Business, Vol. 2, No. 4, PP.411-427. 